\title{
Impact of uteroplacental insufficiency on ovarian follicular pool in the rat
}

\author{
Valentina Pampanini ${ }^{*} \mathbb{D}^{\mathbb{D}}$, Kirsi Jahnukainen ${ }^{1}$, Lena Sahlin', Daniela Germani ${ }^{2}$, Antonella Puglianiello², \\ Stefano Cianfarani ${ }^{1,3}$ and Olle Söder ${ }^{1}$
}

\begin{abstract}
Background: A low oxygen supply to the fetus causes intrauterine growth restriction and can affect gonadal development of the offspring, having a potential impact on fertility. We investigated histology and gene expression in the postnatal rat ovary after fetal hypoxia induced by uterine artery ligation.

Methods: Sprague-Dawley rats underwent uterine artery ligation at day 19 of gestation. Offspring were sacrificed at 5, 20 and 40 days post-partum. Follicles were counted and classified in hematoxylin-eosin stained sections. Gene expression of 90 genes was analyzed by TaqMan Low Density Array.

Results: A significantly lower number of total and primordial follicles was detected in 20 days post-partum intrauterine growth restricted animals. Follicle density was not different at 40 days post-partum, suggesting that compensatory mechanisms occurred during the pre-pubertal window. Uterine artery ligation modified the expression of 24 genes involved in different cellular functions, among which proliferation, apoptosis and metabolism.

Conclusion: Ovarian follicle pool was affected by fetal hypoxia in early life, but this effect did not persist in puberty. Genes involved in cellular processes were affected at all ages, potentially implying long-term genetic alterations. Further analyses are needed to elucidate later effects of fetal hypoxia on ovarian function and fertility.
\end{abstract}

Keywords: Ovary, Follicle reserve, Intrauterine growth restriction, Developmental origins of health and disease

\section{Background}

In the early '90s David Barker and colleagues published several epidemiological studies correlating birth weight with metabolic risk and rates of death for cardiovascular diseases in adulthood [1-6]. These observations gave origin to the theory that adult diseases' predisposition originates in fetal life, as a consequence of a suboptimal intrauterine environment leading to poor growth of the fetus [4]. This theory has been later defined 'Developmental Origins of Health and Disease' (DOHaD) hypothesis [7] and supported by a wealth of scientific evidence. Adverse in utero conditions have been proven to permanently shape gene expression, thereby affecting the structure and function of different organs [8]. Pathological events during fetal development encompass

\footnotetext{
* Correspondence: valentina.pampanini@ki.se

${ }^{1}$ NORDFERTIL Research Lab Stockholm, Pediatric Endocrinology Unit, Department of Women's and Children's Health, Karolinska Institutet and University Hospital, Visionsgatan 4; J9:30, SE-171 64, Solna, Stockholm, Sweden

Full list of author information is available at the end of the article
}

maternal malnutrition, placental dysfunction and maternal inflammatory status. Placental insufficiency, leading to a compromised blood flow to the fetus, fetal hypoxia and consequent intrauterine growth restriction (IUGR), is the most common cause of IUGR in Western countries. Smallness for gestational age has been used in clinical studies as a surrogate measure of IUGR, although the two entities may not be the same.

Altered sexual maturation has been reported in low birth-weight/small for gestational age (SGA) children [9-11]. Girls born SGA have higher FSH levels during infancy $[12,13]$, an earlier onset of puberty $[14,15]$ and a lower age at menarche [15-17] than those with a birth weight appropriate for gestational age (AGA).

A higher prevalence of anovulation and smaller ovaries at ultrasound measurements were shown in post-menarcheal girls born SGA compared to AGA counterparts [18-20]. In rodents and ovine, IUGR induced by maternal undernutrition caused DNA damage in fetal oogonia [21] and affected folliculogenesis $[22,23]$. We have previously shown that

(c) The Author(s). 2019 Open Access This article is distributed under the terms of the Creative Commons Attribution 4.0 International License (http://creativecommons.org/licenses/by/4.0/), which permits unrestricted use, distribution, and reproduction in any medium, provided you give appropriate credit to the original author(s) and the source, provide a link to the Creative Commons license, and indicate if changes were made. The Creative Commons Public Domain Dedication waiver (http://creativecommons.org/publicdomain/zero/1.0/) applies to the data made available in this article, unless otherwise stated. 
IUGR induced by uteroplacental insufficiency (UPI) altered the morphology and the gene expression profile in the testes of postnatal rats [24]. In female rats, UPI was shown to delay pubertal development and to reduce the number of follicles in adulthood [25].

Here, we used the same animal model to investigate the effect of IUGR on the gene expression and the follicle pool in ovaries of rats from neonatal to peripubertal ages.

\section{Material and methods \\ Animals}

All protocols for the study were approved by the Committee for Animal Research of Tor Vergata University, Rome, Italy. Animal experiments were performed according to the Guide for the Care and Use of Laboratory Animals of the National Institutes of Health (NIH Publication No. 85-23, revised 1996). All procedures complied with Italian regulations for laboratory animal care, according to the guidelines and under supervision of the Animal Technology Station, Interdepartmental Service Center, Tor Vergata University, Rome, Italy.

The animal model was developed as previously described [24]. Briefly, time-dated Sprague-Dawley pregnant rats (Charles River Laboratories Inc., Italy) were delivered to the animal facilities at least 3 days prior to the first surgery. IUGR was induced by bilateral ligation of the uterine arteries on day 19 of gestation, according to the method described from Wigglesworth in 1964 [26]. Control animals (shams) were born from mothers that underwent the same surgical procedure, with the exception of uterine artery ligation. Dams delivered spontaneously during the night between day 22 and 23 . Animals were selected as significant IUGR if their birth weight (BW) was more than 2 standard deviations (SDS) below the mean BW of the control litter. Newborn pups were assigned to feeding dams with a maximum number of six offspring per litter. Pup weight was recorded on day 0 and thereafter once a week until the end of experiments. However, it was not possible to follow individual animals until sacrifice or until the age of 3 weeks when the ear tag was placed. At 21 days post-partum (dpp), pups were weaned onto standard rat chow diet (Mucedola S.R.L., Milano, Italy), separated from dams and placed in groups of three to five, with the males and females separated. For the purpose of this study only female pups were evaluated. The results of the analyses on male pups have been reported earlier [24]. Animals were sacrificed through cervical dislocation at postnatal days 5, 20 and $40 \mathrm{~d} p p$. These age points represent in the rat the neonatal (end of follicular assembly), juvenile (appearance of the first large antral follicles and atresia of medullary follicles) and peripubertal (first ovulation) periods [27]. In order to ensure biological variability of the observed phenotype, each group of IUGR and shams at 20 and $40 \mathrm{~d} p p$ included six animals from at least three different litters. For the $5 \mathrm{~d} p p$ old animals, starting material included eight IUGR and four sham animals, also derived from three different litters. For all of them body and ovary weight were measured. Gene expression analysis was carried in 6 IUGR and 3 sham animals. Histological evaluation was performed in 4 IUGR and 4 sham animals.

\section{Tissue processing and immunohistochemistry-anti- Mullerian hormone (AMH)}

At sacrifice, ovaries were immediately excised from euthanized animals and processed as previously described [24]. In brief, for histological purpose, one gonad was fixed in 4\% paraformaldehyde (PFA; P/N15812-7, Sigma-Aldrich, MO, USA) overnight at $4{ }^{\circ} \mathrm{C}$, serially dehydrated in increasing concentration of aqueous ethanol followed by $100 \%$ butyl acetate (P/N 45860, Sigma-Aldrich, MO, USA) and finally embedded in paraffin (Paraplast X-TRA ${ }^{\circ} ; \mathrm{P} / \mathrm{N}$ P3808, Sigma-Aldrich) at $61^{\circ} \mathrm{C}$ overnight. Ovaries were cut serially to a thickness of five $\mu \mathrm{m}$, using a Biocut sectioning machine (Reichert-Jung, NY, USA), mounted on microscope slides (P/N10143352, Superfrost Plus, Thermo Scientific, MA, USA) and placed at $37^{\circ} \mathrm{C}$ overnight.

For immunohistochemical (IHC) analysis, three sections per ovary corresponding to $\sim 25,50$ and $75 \%$ points of the entire tissue block (i.e. 25th, 50th and 75th sections when the total number was 100) were stained and evaluated [28]. Tissue sections were dewaxed with xylene (P/N 02080, HistoLab, Gothenburg, Sweden) for $10 \mathrm{~min}$ and then serially rehydrated with decreasing concentrations of aqueous ethanol. Antigen retrieval was performed using citrate buffer $(\mathrm{pH} 6.0)$ at $95^{\circ} \mathrm{C}$ for 10 min. Slides were then incubated with $3 \% \mathrm{H}_{2} \mathrm{O}_{2}$ in methanol for $10 \mathrm{~min}$ at RT for endogenous peroxidase blocking followed by incubation with $2 \%$ horse serum in $1 \times$ tris-buffered saline (TBS) for $30 \mathrm{~min}$ at RT to prevent nonspecific antibody binding. Afterwards, samples were incubated with primary antibody against AMH (P/N MCA2246, Biorad, CA, USA) or unspecific IgGs (for negative control) dissolved in $2 \%$ horse serum in TBS overnight at $4{ }^{\circ} \mathrm{C}$. After washing with TBS plus $0.01 \%$ Tween20 (P/N P1379, Sigma Aldrich,), slides were incubated with biotinylated secondary antibody (P/N BA1400, Vector laboratories, CA, USA), and then with avidin-biotin-peroxidase complex prepared using Vectastain $\mathrm{ABC}$ kit (P/N PK-6100, Vector Laboratories, CA, USA) for 30 min each at $37^{\circ} \mathrm{C}$. After washing again twice, slides were stained with DAB (P/N SK-4105, Vector Laboratories,) at RT, counter-stained with hematoxylin solution modified according to Gill III, rinsed for 5 min with running tap water, dehydrated with gradually increasing concentrations of ethanol, cleared with xylene and finally 
mounted using Pertex (Cell Path, Hemel Hempstead, UK) and cover slips.

\section{Histomorphometry and follicle counts}

For histological evaluations, ovarian sections were stained with hematoxylin and eosin. In brief, following dewaxing in xylene and serial rehydration in ethanol, samples were washed twice with distilled water, incubated for 3 min with hematoxylin solution modified according to Gill III and then rinsed with tap water for 20 min, followed by 70 and $95 \%$ ethanol baths for $5 \mathrm{~min}$ each. Slides were finally incubated with eosin for $30 \mathrm{~s}$, dehydrated with $100 \%$ ethanol for $5 \mathrm{~min}$ and $100 \%$ xylene twice for $5 \mathrm{~min}$, and finally mounted with Pertex (Cell Path, Hemel Hempstead, UK) and cover slips. Three sections per ovary, corresponding to $\sim 25,50$ and $75 \%$ points of the entire tissue block [28], were selected for follicle quantification. For each section, only follicles with a visible nucleus were counted and classified as follows: (1) primordial follicles (PF), with one layer of flattened pre-granulosa cells (GCs); (2) primary, with two or more cuboidal GC up to one complete layer of cuboidal GCs; (3) secondary, with a least two layers of GCs but no antrum; and (4) tertiary, where the antrum was visible [29, 30]. Two blinded observers evaluated the same sections independently and the results were compared showing an inter-observer concordance above $90 \%$.

Corpora lutea $(\mathrm{CL})$ were quantified in the same three sections per animal as an indirect measure of the ovulation rate.

The ovary was approximated to a prolate ellipsoid [31] and the ovarian volumes $\left(\mathrm{mm}^{3}\right)$ extrapolated using the ellipsoid formula $4 / 3 \pi$ a $b^{2}$, where ' $a$ ' is the length of the entire ovary derived by multiplying the total number of sections $(n)$ by 0.005 (representing the thickness of each section), and $\pi b^{2}$ is the Area of the middle section (Am) of the ovary. Therefore, ovarian volume $(V)=4 / 3$ * $\mathrm{A} m{ }^{*} n * 0.005$.

\section{RNA isolation and CDNA synthesis}

Total RNA was extracted from whole frozen ovaries and stored at $-80^{\circ} \mathrm{C}$ using an RNeasy Mini Kit (P/N 74104, Qiagen, Veno, Netherlands). In brief, samples were dissolved in Qiagen lysis buffer and then homogenized twice for $30 \mathrm{~s}$ in an ULTRA-TURRAX T25 homogenizer (JANKE and KUNKEL, Staufen, Germany). Subsequently, the supernatant was mixed with half its volume of $70 \%$ ethanol. The mixture was then transferred to RNeasy spin columns and processed according to the manufacturer's protocol.

RNA concentrations were quantified using a single-beam UV/vis spectrophotometer (P/N 6132000032, Eppendorf, Hamburg, Germany). To generate cDNA, one $\mu \mathrm{g}$ of total RNA was reverse-transcribed on a thermocycler $(\mathrm{P} / \mathrm{N}$
4359659, Applied Biosystems, MA, USA) using random hexamers in a total reaction volume of $20 \mu \mathrm{l}$. The IScript ${ }^{\mathrm{mi}}$ cDNA synthesis kit (P/N 170-8891, Bio-Rad, CA, USA) was used as instructed by the manufacturer.

\section{TaqMan low-density arrays (TLDAs)}

TLDA cards (P/N 4342259, ABI, Hilden, Germany) were used for comparative analysis of gene expression of IUGR and control animals, according to the manufacturer's protocol, as previously described [24]. Briefly, the TLDA cards are based on TaqMan chemistry where gene expression of a panel of 96 genes is analyzed in one run. The TLDA cards were pre-loaded with 96 TaqMan gene expression assays of importance for proliferation, apoptosis, cellular energy, germ cell and somatic cell function and differentiation, and six endogenous controls assigned for normalization. Gene expression was normalized to the mean of five out of six endogenous controls (Actin beta, Beta-2-microglobulin, Catenin beta 1, Eukaryotic translation elongation factor 1 alpha 1 and Glyceraldehyde-3-phosphate dehydrogenase) of the same sample $(\mathrm{dCt})$, selected according to their stability. Data from one randomly chosen animal were used as a calibrator (ddCT) and data from all other animals were normalized to it. Gene expression was finally presented as relative expression [using the fold change $(2-\mathrm{ddCT})$ method for calculation].

TaqMan Gene expression Master Mix (P/N 4369510, Applied Biosystems, MA, USA) was used when running the TLDA assays.

\section{Serum AMH measurement}

AMH serum levels were measured in 5, 20 and $40 \mathrm{~d} p p$ animals by Gen II ELISA Reagent kit REF A79765 and Calibrator kit A79766 (Beckman Coulter) in accordance with manufacturer's protocol. Detection limit was 0.08 $\mathrm{ng} / \mathrm{mL}$ and the intra and inter-assay variations were 4.3 and $9.8 \%$, and 1.4 and $4.3 \%$, for the low and high levels of the standard curve, respectively.

\section{Statistical analysis}

Data are expressed as mean \pm SD. The variables among groups were compared using Student's T-test, based on Shapiro-Wilk normality test. Differences were considered statistically significant at $P<0.05$. All analyses were performed using the SigmaStat ( $v$ 11.00) package (SPSS, Inc., IL, USA).

\section{Results}

Body weight, ovarian size and ovarian histology

Body weights (BW) and ovarian weights (OW) of IUGR and sham animals are shown in Table 1.

Mean BW in IUGR rats was still significantly reduced at $5 \mathrm{~d} p p$ compared to sham rats but caught up by 20 
Table 1 Body weight, ovarian weight and their ratio in IUGR and sham rats

\begin{tabular}{|c|c|c|c|c|c|c|c|c|c|}
\hline & \multicolumn{3}{|l|}{$5 \mathrm{~d} p p$} & \multicolumn{3}{|l|}{$20 \mathrm{~d} p p$} & \multicolumn{3}{|l|}{$40 \mathrm{~d} p p$} \\
\hline & $\begin{array}{l}\text { IUGR } \\
(n=8)\end{array}$ & $\begin{array}{l}\text { Sham } \\
(n=4)\end{array}$ & $P$ & $\begin{array}{l}\text { IUGR } \\
(n=6)\end{array}$ & $\begin{array}{l}\text { Sham } \\
(n=6)\end{array}$ & $P$ & $\begin{array}{l}\text { IUGR } \\
(n=6)\end{array}$ & $\begin{array}{l}\text { Sham } \\
(n=6)\end{array}$ & $P$ \\
\hline BW (g) & $10.6 \pm 0.9$ & $12.4 \pm 0.5$ & 0.004 & $55.8 \pm 6.8$ & $57.7 \pm 6.3$ & 0.662 & $152.1 \pm 22.6$ & $159.1 \pm 15.4$ & 0.628 \\
\hline$O W \times 10 \wedge^{3}(g)$ & $2.5 \pm 1.4$ & $2.7 \pm 0.6$ & 0.933 & $19.2 \pm 4.7$ & $16.1 \pm 7.6$ & 0.394 & $46.0 \pm 15.0$ & $55.9 \pm 8.81$ & 0.234 \\
\hline$O W: B W \times 10 \wedge^{3}(\mathrm{~g} / \mathrm{g})$ & $0.2 \pm 0.1$ & $0.2 \pm 0.0$ & 0.808 & $0.3 \pm 0.1$ & $0.3 \pm 0.1$ & 0.818 & $0.3 \pm 0.0$ & $0.3 \pm 0.1$ & 0.234 \\
\hline
\end{tabular}

Values are expressed as means \pm standard deviations. BW, body weight; dpp, days post-partum; IUGR, intrauterine growth restricted; OW, ovarian weight Bold characters emphasize significant $P$-values

$\mathrm{d} p p$. Ovarian weight $(\mathrm{OW})$ and $\mathrm{OW}$ normalized per body weight (OW:BW) were not significantly different in the two groups (Table 1).

In both groups, PF density declined from 5 to $40 \mathrm{dpp}$, in line with the expected age-related decrease in the number of PF from birth to puberty, that has been well-described in other mammalian species, i.e. humans and primates [32-34] (Additional file 1: Figure S1A). However, in IUGR rats at $5 \mathrm{~d} p p$ PF and total follicle showed a tendency to be lower compared to controls, although the comparison did not reach statistical significance. At $20 \mathrm{~d} p p$, the number of PF and total follicles was significantly reduced in the ovaries of IUGR rats compared to sham (Fig. 1).

At $40 \mathrm{~d} p p$ no differences in the number of follicles were noted between the two groups of animals.

The ratio between growing follicles (primary, secondary and tertiary) and total follicles was calculated in order to evaluate a possible change in activation of $\mathrm{PF}$ and their subsequent transition into the pool of growing follicles. No difference was detected in the ratio between the groups at any age (Fig. 1).

Extrapolated ovarian volumes and CL number was also comparable between the groups (data not shown).

\section{Networks of genes affected by IUGR}

We analyzed the relative expression of a panel of 90 genes that were selected because of their known functions in the gonads (Table 2).
In IUGR ovaries, 24 genes were differentially regulated as compared to controls (Table 3).

Among those, six genes showed a significantly higher expression and 18 genes showed a significantly lower expression in IUGR versus sham animals (Fig. 2).

Six genes involved in cell proliferation, survival and cycle regulation were significantly dysregulated in IUGR rats at $40 \mathrm{~d} p p$ compared to controls. In addition, five genes were modified concordantly towards a reduction in the proliferation rate of ovarian cells, namely Proliferation-related Ki67 antigen (MKi67), Proliferating cell nuclear antigen (Pcna), Cyclin-dependent kinase inhibitor 1B (Cdkn1b), DNA topoisomerase II (Top2a) and Thymidine kinase 1 (Tk1). The gene encoding for Caspase 9 (Casp9) was also downregulated at this age.

Three genes involved in ovarian angiogenesis were dysregulated in $20 \mathrm{~d} p p$ IUGR ovaries compared to sham ones, Angiopoietin 1 (Angpt1) and Transforming growth factor beta 2 ( $T g f b 2)$ expression was reduced, whereas Platelet derived growth factor receptor alpha polypeptide (Pdgfra) was upregulated.

Furthermore, IUGR animals showed a lower expression of Insulin-like growth factor (IGF) 1 receptor (Igf1r) both at 20 and $40 \mathrm{~d} p p$, that together with the increased expression of IGF binding protein (Igfbp3) at $40 \mathrm{~d} p p$ pointed towards a downregulation of the IGF signaling within the ovary of IUGR rats.

The expression of four genes involved in the regulation of cellular metabolism was altered in IUGR animals

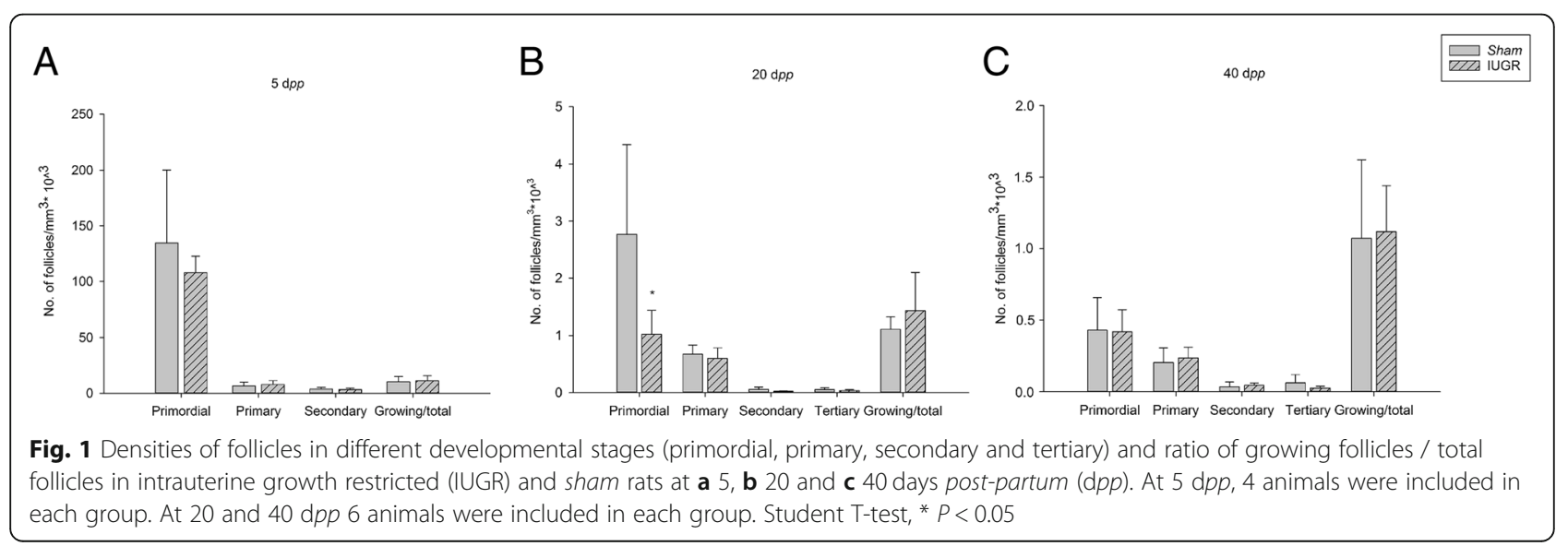


Table 2 Abbreviations and names of the significantly dysregulated genes in sham versus IUGR rats from the TLDA analysis

\begin{tabular}{|c|c|}
\hline Gene symbol & Name \\
\hline Amh & Anti-Mullerian hormone \\
\hline Angpt1 & Angiopoietin 1 \\
\hline Casp9 & Caspase 9 \\
\hline Cdkn1B & Cyclin-Dependent Kinase Inhibitor 1B (P21, Cip1) \\
\hline Cs & Citrate Synthase \\
\hline Fgf4 & Fibroblast Growth Factor 4 \\
\hline Fgf5 & Fibroblast Growth Factor 5 \\
\hline Gata6 & GATA binding protein 6 \\
\hline $\operatorname{lgf} 1 \mathrm{r}$ & Insulin-Like Growth Factor 1 Receptor \\
\hline $\operatorname{lgfbp3}$ & Insulin-like growth factor binding protein 3 \\
\hline Inhbb & Inhibin subunit beta $B$ \\
\hline Insl3 & Insulin-like 3 \\
\hline Ldhb & Lactate Dehydrogenase b \\
\hline Ldhc & Lactate Dehydrogenase C \\
\hline Mki67 & Marker of proliferation Ki-67 \\
\hline Pcna & Proliferating cell nuclear antigen \\
\hline Pdgfra & Platelet derived growth factor receptor alpha \\
\hline Slc2a1 & $\begin{array}{l}\text { Solute Carrier Family } 2 \text { (Facilitated Glucose Transporter), } \\
\text { Member } 1\end{array}$ \\
\hline Tgfb1 & Transforming growth factor, beta 1 \\
\hline Tgfb2 & Transforming growth factor, beta 2 \\
\hline Thy 1 & Thy-1 Cell Surface Antigen \\
\hline Tk1 & Thymidine Kinase 1, Soluble \\
\hline Top2a & DNA topoisomerase II alpha \\
\hline Zbtb16 & Zinc finger and BTB domain containing 16 \\
\hline
\end{tabular}

IUGR intrauterine growth restricted, TLDA TaqMan low density array

at different time points, as compared to sham; in particular Lactate dehydrogenase-c $(L d h-c)$ and Citrate synthase $(C s)$ were downregulated at $5 \mathrm{~d} p p$ and $40 \mathrm{~d} p p$, respectively. In IUGR rats at $20 \mathrm{~d} p p L d h-b$ and $L d h-c$ were both upregulated and Solute carrier family 2 member 1 (Slc2a1) was upregulated at $40 \mathrm{~d} p p$.

Gene encoding for AMH (Amh) showed a reduced expression in IUGR ovaries at $20 \mathrm{~d} p p$ compared to controls. Inhibin B (Inhbb) expression was also lower at 40 $\mathrm{d} p p$ in IUGR rats versus sham ones. In Fig. 3 the expression of 8 representative genes from IUGR and sham ovaries at the three age points is reported.

\section{AMH assessment}

Given the role of AMH as an indirect marker of ovarian reserve [35], we evaluated serum AMH levels in the two groups of animals. No significant difference was detected although a tendency to lower AMH concentrations in
IUGR rats at all ages was observed (Additional file 1: Figure S1B).

In order to analyze whether a tendency to lower serum $\mathrm{AMH}$ and a lower expression of the gene encoding for AMH was related to a lower protein synthesis from the follicles, expression of ovarian AMH was evaluated by IHC; the analysis did not show any clear difference in the intensity of protein expression in granulosa cells between the groups (Additional file 1: Figure S1C).

\section{Discussion}

Fetal life is the first fundamental window of susceptibility to pathogenic noxae for the individual. Events occurring during this period have been associated with gene reprogramming and modification of organ functions that can persist throughout the entire lifespan. Using the same animal model, we have previously demonstrated that in utero growth restriction altered size and morphology of the testis in neonatal rats and induced modifications of gene expression up to the peripubertal age [24]. Here, for the first time, we provide evidence of the effects of UPI during late gestation on the ovarian follicular pool and on the expression of genes involved in ovarian cellular processes.

In this study, we observed that the number of PF, constituting the ovarian reserve, was reduced at birth by fetal hypoxia and continued to diminish until the age of $20 \mathrm{~d} p p$. In addition, we were able to demonstrate that UPI during late gestation induced alterations in the expression of multiple genes in the neonatal, prepubertal and peripubertal rat ovary.

A decrease in the number of follicles has been reported in rat models where IUGR was induced by different means, from maternal food restriction [22] to inflammation [36]. Our study is concordant with a previous study from Engelbregt and colleagues that observed a decrease in total, primordial and growing follicles in adult rats with IUGR induced by uterine artery ligation [25] and it is the first exploring changes in the ovary throughout postnatal development.

A reduction in the number of PF has also been detected in the ovaries of human fetuses who had restricted growth [37]. Poor growth in utero has been associated to an increased incidence of polycystic ovarian syndrome (PCOs) that may in turn cause reduced fertility $[9,38]$. Despite some studies suggest that adverse events during fetal life can induce premature ovarian failure in women, data in this respect remain inconclusive [14]. In this frame, our study provides evidence of a qualitative and quantitative influence of fetal growth restriction on the ovarian follicle pool.

Despite the lower follicle number at prepubertal ages, we could not see any difference in follicle counts at the age of $40 \mathrm{~d} p p$, indicating that long-term ovarian reserve 
Table 3 Significant gene expression changes between sham and IUGR rats at 5, 20 and $40 \mathrm{dpp}$

\begin{tabular}{|c|c|c|c|c|}
\hline \multirow[t]{2}{*}{ Cluster } & \multirow[t]{2}{*}{ Gene } & \multicolumn{3}{|l|}{ Sham vs IUGR } \\
\hline & & $\mathrm{d} p p 5$ & $\mathrm{dpp} 20$ & $\mathrm{dpp} 40$ \\
\hline \multirow[t]{5}{*}{ Proliferation } & Mki67 & & & $1.0 \pm 0.3$ vs $0.5 \pm 0.2$ \\
\hline & Pcna & & & $1.0 \pm 0.1$ vs $0.6 \pm 0.2$ \\
\hline & $C d k n 1 b$ & & & $1.0 \pm 0.3$ vs $0.7 \pm 0.1$ \\
\hline & Top2a & & & $1.0 \pm 0.2$ vs $0.4 \pm 0.1$ \\
\hline & $T k 1$ & & & $1.1 \pm 0.6$ vs $0.4 \pm 0.2$ \\
\hline Apoptosis & Casp9 & & & $1.0 \pm 0.1$ vs $0.8 \pm 0.1$ \\
\hline \multirow[t]{4}{*}{ Energetics } & Cs & & & $1.0 \pm 0.2$ vs $0.8 \pm 0.1$ \\
\hline & $L d h b$ & & $1.0 \pm 0.2$ vs $1.3 \pm 0.3$ & \\
\hline & Ldhc & $1.0 \pm 0.3$ vs $0.6 \pm 0.1$ & & \\
\hline & Slc2al & & & $1.0 \pm 0.3$ vs $1.6 \pm 0.5$ \\
\hline \multirow[t]{4}{*}{ Angiogenesis } & Tgfb 1 & $1.0 \pm 0.1$ vs $0.7 \pm 0.1$ & & \\
\hline & Tgfb2 & & $1.0 \pm 0.3$ vs $0.7 \pm 0.3$ & \\
\hline & Angpt1 & & $1.0 \pm 0.1$ vs $0.8 \pm 0.3$ & \\
\hline & Pdgfra & & $1.0 \pm 0.1$ vs $1.4 \pm 0.1$ & \\
\hline \multirow[t]{2}{*}{ Insulin/IGF pathways } & lgfir & & $1.0 \pm 0.3$ vs $0.8 \pm 0.1$ & $1.0 \pm 0.2$ vs $0.8 \pm 0.1$ \\
\hline & $\operatorname{lgfbp3}$ & & & $1.0 \pm 0.4$ vs $3.0 \pm 0.9$ \\
\hline \multirow[t]{4}{*}{ Germ cell markers } & Fgf4 & $1.1 \pm 0.4$ vs $0.6 \pm 0.2$ & & \\
\hline & Fgf5 & & $1.5 \pm 1.5$ vs $0.2 \pm 0.1$ & \\
\hline & Thy 1 & $1.0 \pm 0.3$ vs $1.4 \pm 0.2$ & & \\
\hline & Zbtb16 & $1.1 \pm 0.5$ vs $0.5 \pm 0.2$ & & \\
\hline \multirow[t]{3}{*}{ GC markers } & Amh & & $1.0 \pm 0.1$ vs $0.8 \pm 0.1$ & \\
\hline & Inhbb & & & $1.0 \pm 0.1$ vs $0.5 \pm 0.3$ \\
\hline & Gata6 & & & $1.0 \pm 0.2$ vs $0.7 \pm 0.1$ \\
\hline TC markers & $\ln s / 3$ & & $1.1 \pm 0.6$ vs $3.0 \pm 1.9$ & \\
\hline
\end{tabular}

Values are expressed as means \pm standard deviations of gene expression fold changes. Dpp, days post-partum; GC, granulosa cell; IGF, insulin growth factor; IUGR, intrauterine growth restricted; TC, theca cell. Student T-test, $P<0.05$. For the list of gene names and abbreviation please refer to Table 2 . At the age of $5 \mathrm{~d} p p, 6$ IUGR versus 3 sham rats were included. At 20 and $40 \mathrm{dpp}, 6$ animals per group were included

was not affected and eventually that fertility was preserved after hypoxia occurring during late gestation. Recent studies in mice have raised the theory that two different classes of PF exist in the ovary: i) a "first wave" of PF, that is activated immediately after birth, persists in the mouse ovary up to $\sim 3$ months and contributes to the onset of puberty and to the early fertility; ii) an "adult wave" of PF, that is activated gradually after puberty and provides fertility until the end of reproductive life [39-41]. In this view, it is intriguing to speculate that late gestation hypoxia in our model might have affected the first wave of $\mathrm{PF}$ while leaving the adult pool unaffected. A lower number of PF from the first wave at 20 $\mathrm{d} p p$ could therefore explain the decreased number of $\mathrm{PF}$ observed at that age, which was no more evident at 40 $\mathrm{d} p p$ when PF from the non-affected adult wave become more prevalent.

The existence of two populations of follicles with different temporal distribution and susceptibility to pathogenic noxae would represent a fascinating biological mechanism. It would indeed imply that the developing ovary retain a compensatory capacity to ovarian damages which is lost as soon as the first wave of follicles is exhausted (i.e. after puberty). Presently there are no histological markers to distinguish the two populations of follicles.

The existence of ovarian stem cells (OSCs) has been debated in the last 15 years, since Tilly's group claimed the detection of ovarian germ cell progenitors in the ovary [42-44]. Their findings have raised controversy and several studies have tried to address the issue with contradictory results [45]. Hence, an indisputable proof of the existence of these cells in the mammalian ovary and a protocol able to identify OSCs is still missing [45].

Nevertheless, the hypothesis that these cells reside in the ovary in a quiescent state and are activated in response to oocyte damage is still subjected to investigation and offer an intriguing alternative explanation to our findings. 


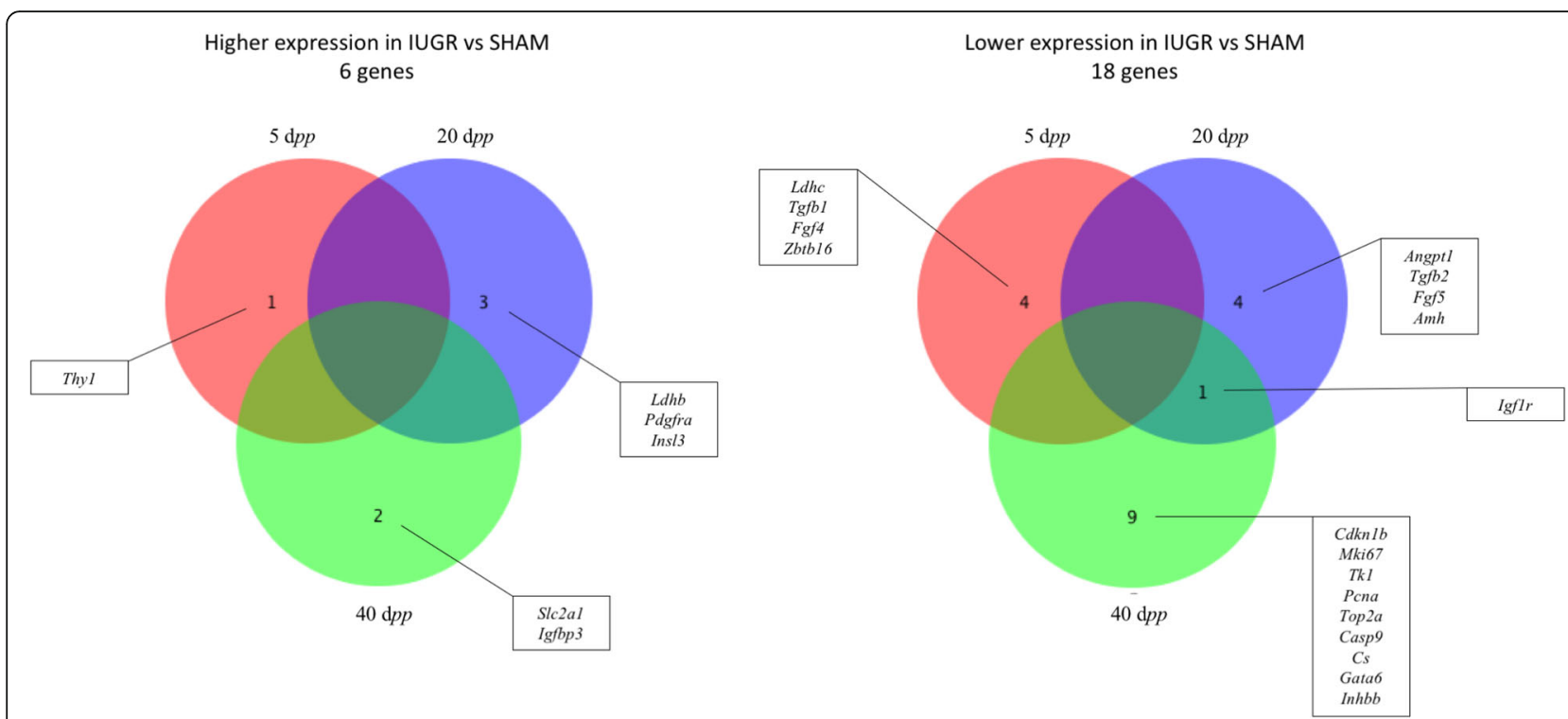

Fig. 2 Venne diagrams representing genes with significantly higher and lower expression in intrauterine growth restricted (IUGR) vs sham rats at 5, 20 and 40 days post-partum (dpp) from TaqMan Low-Density Array analysis. Gene abbreviations and corresponding names are listed in Table 2

Another interesting mechanism for the comparable PF density between groups at day 40 could be a lower rate of follicular attrition in IUGR rats between 20 and 40 $\mathrm{d} p p$ of age compared to sham ones. This phenomenon could be driven by the gene modifications observed in IUGR rats. Consistently, the expression of the gene encoding for CASPASE 9, a significant protein in the apoptotic cascade, was significantly downregulated at day 40 in IUGR rats compared to controls. In addition, previous studies in knock-out mice models have suggested that the Transforming growth factor beta 2 (TGFB2) has a role in the mediation of oocyte apoptosis during the embryonic stage. In our IUGR rats, expression of $T g f b 2$ was reduced at day 20 allowing us to speculate of a possible implication of this factor in the control of apoptosis also during postnatal life.

Furthermore, increased activation and recruitment of PF into the growing pool has been proposed, in other pathogenic frames, as a mechanism that can eventually lead to ovarian reserve exhaustion [46]. An increased entry of PF into the pool of growing follicles could justify their reduction at day 20 . However, we were not able to show any increase in the activation rate of PF, based on the ratio between growing follicles and total follicles. This was consistent with the expression of 5 different genes involved in cell proliferation (i.e. Cdkn1b, Mki67, Tk1, Pcna, Top 2a) that was reduced in IUGR rat ovaries at $40 \mathrm{~d} p p$. These changes could reflect a lower activation rate of PF, ultimately compensating the PF loss induced by the UPI. The same significance could be attributed to the modifications of genes belonging to the IGF system: the reduction of Igflr at both day 20 and 40 and the parallel increase in $I g f b p 3$ expression at day 40 predicts a reduction in the activity of IGF-I, one of the most important growth factors, within the ovary.

Finally, some of the gene modifications occurring at $20 \mathrm{~d} p p$ and not observed at day 40, could reflect the shift from lactation to standard rat chow diet, as weaning happened coincidentally ( $21 \mathrm{~d} p p)$. Although most of the studies have focused on non-physiological dietary regimens (i.e. food restriction or high-fat diet) to test the effects on gene expression in different organs, normal weaning was shown to alter the mRNA levels of 18 genes in piglet small intestine [47].

Our study has a few potential limitations. First, pubertal onset and progression and sex steroid hormone profile were not evaluated in the experimental animals. Given the hypothesis that follicles from the first wave contribute to the onset of puberty and to the establishment of the hypothalamus-pituitary-ovarian axis, this information could have been supportive to the data. Second, we did not assess fertility in IUGR rats by verifying mating outcomes. Whether a normal number of follicles at peripubertal age reflects an intact fertility potential and above all is maintained throughout the reproductive lifespan in rats exposed to fetal hypoxia remains to be ascertained. Third, due to the limited amount of tissue available, it was not possible to verify gene expression data at the protein level, therefore results of our study have to be interpreted carefully, bearing in mind that post-transcriptional modifications could alter the functional outcome. The method we used to generate IUGR leads to a rapid disruption of ovarian perfusion by uterine artery ligation in late 


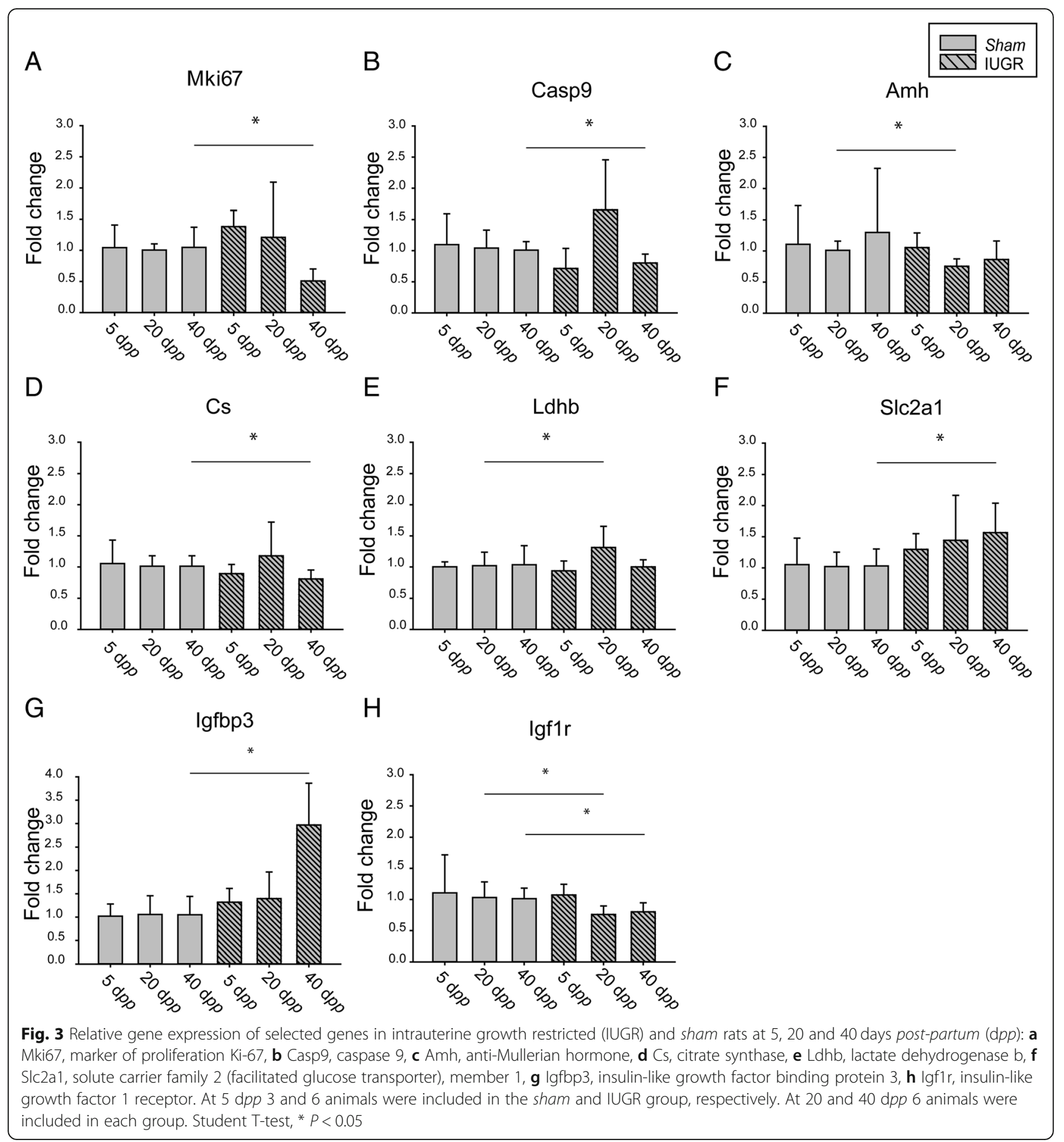

gestation, which is different from the gradual onset of hypoxia that may occur more slowly during the human pregnancy. Furthermore, we investigated the effects of a late-onset placental insufficiency, whereas human fetal growth restriction is often the consequence of a disrupted placental development with earlier and sustained onset. Therefore, despite these data appear reassuring, more studies are required to investigate if the full reproductive lifespan is affected in the human pathogenic setting. Finally, it has to be pointed out that all animals showed early postnatal catch-up growth, normalizing their body size soon after birth. Therefore, the fate of ovaries in animals that remain permanently small (as occurs in almost $10 \%$ of children born SGA) remains unknown. Inter-species differences between rats and humans need also to be taken into account when translating these results to human pathology. 


\section{Conclusions}

In conclusion, we demonstrated that IUGR induced by late gestation hypoxia affects the number of follicles in juvenile rats, in particular targeting primordial follicles. The recovery in follicle number observed at peripubertal ages could be regulated by different mechanisms, putatively involving gene reprogramming, although data in this respect remain preliminary. Despite these results appear reassuring, at least when considering late-onset placental insufficiency, long-term longitudinal studies are required to investigate whether the full reproductive lifespan is affected.

\section{Additional file}

Additional file 1: Figure S1. A) Density of primordial follicles in intrauterine growth restricted (IUGR) and sham rats at 5,20 and 40 days post-partum (dpp). Student T-test, $* P<0.05$. B) Serum levels of anti-Müllerian hormone $(\mathrm{AMH})(\mathrm{ng} / \mathrm{ml})$ in IUGR and sham rats at 5 , 20 and $40 \mathrm{dpp}$. At $5 \mathrm{dpp} 4$ and 7 animals were included in the sham and IUGR group, respectively. At $20 \mathrm{dpp} 6$ animals were included in each group. At $40 \mathrm{dpp} 2$ and 6 animals were included in the sham and IUGR group, respectively. C) Immunohistochemical images of AMH in two representative sections for each age $(5,20$ and $40 \mathrm{dpp})$ in ovaries from IUGR and sham rats. Scale bars correspond to $100 \mu \mathrm{m}$ for $5 \mathrm{dpp}$ animals and to $500 \mu \mathrm{m}$ for 20 and $40 \mathrm{dpp}$ animals (DOCX $334 \mathrm{~kb}$ )

\section{Abbreviations}

AGA: Appropriate for gestational age; Am: Area of the middle section; AMH: Anti-Müllerian hormone; Angpt1: Angiopoietin 1; BW: Birth weight; Casp9: Caspase 9; Cdkn1b: Cyclin-dependent kinase inhibitor 1B; CL: Corpus luteum; DOHaD: Developmental origins of health and disease' hypothesis; Dpp: Days post-partum; GC: Granulosa cells; IGF: Insulin-like growth factor; Igf1r: IGF receptor 1; Igfbp3: IGF binding protein 3;

IHC: Immunohistochemistry; Inhbb: Inhibin B; IUGR: Intrauterine growth restriction; Ldh-b: Lactate dehydrogenase-b; Ldh-c: Lactate dehydrogenase-c; MKi67: Proliferation-related Ki67 antigen; OSCs: Ovarian stem cells;

OW: Ovarian weight; Pcna: Proliferating cell nuclear antigen; PCOs: Polycystic ovarian syndrome; Pdgfra: Platelet derived growth factor receptor alpha polypeptide; PF: Primordial follicles; SDS: Standard deviations; SGA: Small for gestational age; SIc2a1: Solute carrier family 2 member 1; TBS: Tris-buffered saline; Tgfb2: Transforming growth factor beta 2; Tk1: Thymidine kinase 1; TLDA: TaqMan low density array; Top2a: DNA topoisomerase II;

UPI: Uteroplacental insufficiency; V: Volume

\section{Acknowledgements}

The authors are grateful to Kristín Rós Kjartansdóttir and Patrick Muller for their contribution in performing Taq Man Low Density Arrays and to Ahmed Reda and Luise Landreh for their support in performing tissue processing for immunohistochemistry and RNA extraction, respectively.

\section{Funding}

This study was supported by research grants from the Swedish Research Council, Children's Cancer Found, Stockholm County Council Research Funds, the Frimurare Foundation and Karolinska Institutet. Valentina Pampanini received grant support from the Sällskapet Barnavård foundation.

\section{Availability of data and materials}

The datasets used and/or analysed during the current study are available from the corresponding author on reasonable request.

\section{Authors' contributions}

VP: experimental design, data collection and analysis, drafting and revising the manuscript. KJ, LS, SC, OS: experimental design, interpretation of data, drafting and revising the manuscript. DG and AP: experimental design, data collection and revising the manuscript. All the authors have given final approval of the version to be published and agreed to be accountable for all aspects of the work.

\section{Ethics approval}

All protocols for the study were approved by the Committee for Animal Research of Tor Vergata University, Rome, Italy. Animal experiments were performed according to the Guide for the Care and Use of Laboratory Animals of the National Institutes of Health (NIH Publication No. 85-23, revised 1996). All procedures complied with Italian regulations for laboratory animal care, according to the guidelines and under supervision of the Animal Technology Station, Interdepartmental Service Center, Tor Vergata University, Rome, Italy.

\section{Consent for publication}

Not applicable

\section{Competing interests}

The authors declare that they have no competing interests.

\section{Publisher's Note}

Springer Nature remains neutral with regard to jurisdictional claims in published maps and institutional affiliations.

\section{Author details}

${ }^{1}$ NORDFERTIL Research Lab Stockholm, Pediatric Endocrinology Unit, Department of Women's and Children's Health, Karolinska Institutet and University Hospital, Visionsgatan 4; J9:30, SE-171 64, Solna, Stockholm, Sweden. ${ }^{2}$ Department of Systems Medicine, Tor Vergata University, Rome, Italy. 'Dipartimento Pediatrico Universitario Ospedaliero "Bambino Gesù" Children's Hospital - Tor Vergata University, Rome, Italy.

Received: 23 October 2018 Accepted: 3 January 2019

Published online: 10 January 2019

\section{References}

1. Barker DJ. The fetal and infant origins of adult disease. BMJ. 1990;301(6761):1111.

2. Barker DJ, Bull AR, Osmond C, Simmonds SJ. Fetal and placental size and risk of hypertension in adult life. BMJ. 1990;301(6746):259-62.

3. Barker DJ. Fetal origins of coronary heart disease. BMJ. 1995;311(6998):171-4.

4. Barker DJ. The fetal and infant origins of disease. Eur J Clin Investig. 1995; 25(7):457-63.

5. Fall CH, Osmond C, Barker DJ, Clark PM, Hales CN, Stirling Y, et al. Fetal and infant growth and cardiovascular risk factors in women. BMJ. 1995; 310(6977):428-32.

6. Barker DJ, Martyn CN, Osmond C, Hales CN, Fall CH. Growth in utero and serum cholesterol concentrations in adult life. BMJ. 1993;307(6918):1524-7.

7. Hales CN, Barker DJ. The thrifty phenotype hypothesis. Br Med Bull. 2001;60:5-20.

8. Cianfarani S, Agostoni C, Bedogni G, Berni Canani R, Brambilla P, Nobili V, et al. Effect of intrauterine growth retardation on liver and long-term metabolic risk. Int J Obes. 2012;36(10):1270-7.

9. Ibanez L, de Zegher F. Puberty and prenatal growth. Mol Cell Endocrinol. 2006;254-255:22-5.

10. Hernandez MI, Mericq V. Impact of being born small for gestational age on onset and progression of puberty. Best Pract Res Clin Endocrinol Metab. 2008;22(3):463-76

11. Hokken-Koelega AC. Timing of puberty and fetal growth. Best Pract Res Clin Endocrinol Metab. 2002;16(1):65-71.

12. Ibanez L, Potau N, de Zegher F. Ovarian hyporesponsiveness to follicle stimulating hormone in adolescent girls born small for gestational age. J Clin Endocrinol Metab. 2000;85(7):2624-6.

13. Ibanez L, Valls C, Cols M, Ferrer A, Marcos MV, De Zegher F. Hypersecretion of FSH in infant boys and girls born small for gestational age. J Clin Endocrinol Metab. 2002;87(5):1986-8.

14. Verkauskiene R, Petraitiene I, Albertsson Wikland K. Puberty in children born small for gestational age. Horm Res Paediatr. 2013;80(2):69-77.

15. Persson I, Ahlsson F, Ewald U, Tuvemo T, Qingyuan M, von Rosen D, et al. Influence of perinatal factors on the onset of puberty in boys and girls: implications for interpretation of link with risk of long term diseases. Am J Epidemiol. 1999;150(7):747-55. 
16. Ghirri P, Bernardini M, Vuerich M, Cuttano AM, Coccoli L, Merusi I, et al. Adrenarche, pubertal development, age at menarche and final height of full-term, born small for gestational age (SGA) girls. Gynecol Endocrinol. 2001;15(2):91-7.

17. Bhargava SK, Ramji S, Srivastava U, Sachdev HP, Kapani V, Datta V, et al. Growth and sexual maturation of low birth weight children: a 14 year follow up. Indian Pediatr. 1995;32(9):963-70.

18. Ibanez L, Potau N, Enriquez G, de Zegher F. Reduced uterine and ovarian size in adolescent girls born small for gestational age. Pediatr Res. 2000; 47(5):575-7.

19. Ibanez L, Potau N, Ferrer A, Rodriguez-Hierro F, Marcos MV, De Zegher F. Anovulation in eumenorrheic, nonobese adolescent girls born small for gestational age: insulin sensitization induces ovulation, increases lean body mass, and reduces abdominal fat excess, dyslipidemia, and subclinical hyperandrogenism. J Clin Endocrinol Metab. 2002;87(12):5702-5.

20. Ibanez L, Potau N, Ferrer A, Rodriguez-Hierro F, Marcos MV, de Zegher F. Reduced ovulation rate in adolescent girls born small for gestational age. J Clin Endocrinol Metab. 2002;87(7):3391-3.

21. Murdoch WJ, Van Kirk EA, Vonnahme KA, Ford SP. Ovarian responses to undernutrition in pregnant ewes, USA. Reprod Biol Endocrinol. 2003;1:6.

22. Bernal AB, Vickers MH, Hampton MB, Poynton RA, Sloboda DM. Maternal undernutrition significantly impacts ovarian follicle number and increases ovarian oxidative stress in adult rat offspring. PLoS One. 2010;5(12):e15558.

23. Rae MT, Palassio S, Kyle CE, Brooks AN, Lea RG, Miller DW, et al. Effect of maternal undernutrition during pregnancy on early ovarian development and subsequent follicular development in sheep fetuses. Reproduction. 2001;122(6):915-22.

24. Pampanini V, Germani D, Puglianiello A, Stukenborg JB, Reda A, Savchuk I, et al. Impact of uteroplacental insufficiency on postnatal rat male gonad. J Endocrinol. 2017;232(2):247-57.

25. Engelbregt MJ, van Weissenbruch MM, Popp-Snijders C, Delemarre-van de Waal HA. Delayed first cycle in intrauterine growth-retarded and postnatally undernourished female rats: follicular growth and ovulation after stimulation with pregnant mare serum gonadotropin at first cycle. $J$ Endocrinol. 2002;173(2):297-304.

26. Wigglesworth JS. Experimental growth retardation in the Foetal rat. J Pathol Bacteriol. 1964;88:1-13.

27. Picut CA, Dixon D, Simons ML, Stump DG, Parker GA, Remick AK. Postnatal ovary development in the rat: morphologic study and correlation of morphology to neuroendocrine parameters. Toxicol Pathol. 2015;43(3):343-53.

28. Dean A, van den Driesche S, Wang Y, McKinnell C, Macpherson S, Eddie SL, et al. Analgesic exposure in pregnant rats affects fetal germ cell development with inter-generational reproductive consequences. Sci Rep. 2016;6:19789.

29. Gougeon A. Regulation of ovarian follicular development in primates: facts and hypotheses. Endocr Rev. 1996;17(2):121-55.

30. Gougeon A. Human ovarian follicular development: from activation of resting follicles to preovulatory maturation. Ann Endocrinol (Paris). 2010; 71(3):132-43.

31. Rosendahl M, Ernst E, Rasmussen PE, Andersen CY. True ovarian volume is underestimated by two-dimensional transvaginal ultrasound measurement. Fertil Steril. 2010;93(3):995-8.

32. Jones KP, Walker LC, Anderson D, Lacreuse A, Robson SL, Hawkes K Depletion of ovarian follicles with age in chimpanzees: similarities to humans. Biol Reprod. 2007;77(2):247-51.

33. Miller PB, Charleston JS, Battaglia DE, Klein NA, Soules MR. Morphometric analysis of primordial follicle number in pigtailed monkey ovaries: symmetry and relationship with age. Biol Reprod. 1999;61(2):553-6.

34. Wallace $\mathrm{WH}$, Kelsey TW. Human ovarian reserve from conception to the menopause. PLoS One. 2010;5(1):e8772.

35. Broer SL, Broekmans FJ, Laven JS, Fauser BC. Anti-Mullerian hormone: ovarian reserve testing and its potential clinical implications. Hum Reprod Update. 2014;20(5):688-701.

36. Shalom-Paz E, Weill S, Ginzberg Y, Khatib N, Anabusi S, Klorin G, et al. IUGR induced by maternal chronic inflammation: long-term effect on offspring's ovaries in rat model-a preliminary report. J Endocrinol Investig. 2017:40(10):1125-31.

37. de Bruin JP, Dorland M, Bruinse HW, Spliet W, Nikkels PG, Te Velde ER. Fetal growth retardation as a cause of impaired ovarian development. Early Hum Dev. 1998:51(1):39-46.

38. Ibanez L, Potau N, Enriquez G, Marcos MV, de Zegher F. Hypergonadotrophinaemia with reduced uterine and ovarian size in women born small-for-gestational-age. Hum Reprod. 2003;18(8):1565-9.
39. Zheng W, Zhang H, Gorre N, Risal S, Shen Y, Liu K. Two classes of ovarian primordial follicles exhibit distinct developmental dynamics and physiological functions. Hum Mol Genet. 2014;23(4):920-8.

40. Zheng $\mathrm{W}$, Zhang H, Liu K. The two classes of primordial follicles in the mouse ovary: their development, physiological functions and implications for future research. Mol Hum Reprod. 2014;20(4):286-92.

41. Mork L, Maatouk DM, McMahon JA, Guo JJ, Zhang P, McMahon AP, et al. Temporal differences in granulosa cell specification in the ovary reflect distinct follicle fates in mice. Biol Reprod. 2012;86(2):37.

42. Johnson J, Canning J, Kaneko T, Pru JK, Tilly JL. Germline stem cells and follicular renewal in the postnatal mammalian ovary. Nature. 2004; 428(6979):145-50.

43. Johnson J, Skaznik-Wikiel M, Lee HJ, Niikura Y, Tilly JC, Tilly JL. Setting the record straight on data supporting postnatal oogenesis in female mammals. Cell Cycle. 2005;4(11):1471-7.

44. White YA, Woods DC, Takai Y, Ishihara O, Seki H, Tilly JL. Oocyte formation by mitotically active germ cells purified from ovaries of reproductive-age women. Nat Med. 2012;18(3):413-21.

45. Horan CJ, Williams SA. Oocyte stem cells: fact or fantasy? Reproduction. 2017;154(1):R23-35.

46. Kalich-Philosoph L, Roness H, Carmely A, Fishel-Bartal M, Ligumsky H, Paglin S, et al. Cyclophosphamide triggers follicle activation and "burnout"; AS101 prevents follicle loss and preserves fertility. Sci Transl Med. 2013;5(185):185ra62

47. Wang J, Chen L, Li P, Li X, Zhou H, Wang F, et al. Gene expression is altered in piglet small intestine by weaning and dietary glutamine supplementation. J Nutr. 2008;138(6):1025-32.
Ready to submit your research? Choose BMC and benefit from:
- fast, convenient online submission
- thorough peer review by experienced researchers in your field
- rapid publication on acceptance
- support for research data, including large and complex data types
- gold Open Access which fosters wider collaboration and increased citations
- maximum visibility for your research: over $100 \mathrm{M}$ website views per year
At BMC, research is always in progress.
Learn more biomedcentral.com/submissions 